\title{
PERANAN SEL CLARA PADA INFEKSI PARU KRONIS
}

\author{
Ida Yuliana ${ }^{1}$, Soenanto Roewijoko²
}

\begin{abstract}
Abstrak
Penyakit paru kronik seperti penyakit paru obstruktif kronik (PPOK) dan asma merupakan masalah kesehatan global yang menyebabkan peningkatan komorbiditas dan biaya pengobatan. $\mathrm{Hal}$ ini telah membuat para peneliti mencoba mencari berbagai hal yang dapat digunakan untuk dapat mencegah, mendeteksi dan mengintervensi penyakit paru kronik agar didapatkan terapi yang efektif dan spesifik untuk penyakit tersebut. Artikel ini bertujuan untuk menjabarkan karakteristik sel Clara (sel yang terdapat pada dinding bronchioles paru) dan peranannya pada infeksi paru kronis di tingkat molekuler. Beberapa penelitian membuktikan adanya penurunan fungsi sel Clara akibat remodeling epitel pada infeksi paru kronik. Peranan sel Clara diketahui dapat meregulasi proses inflamasi melalui regulasi prilaku makrofag (anti-inflamasi) dan mengembalikan sel epitel respirasi yang rusak ke arah normal (progenitor stem sel). Dengan adanya fungsi yang luas ini diharapkan sel Clara dapat digunakan sebagai dasar untuk mengembangkan terapi terbaru dalam pengobatan penyakit infeksi paru kronik.
\end{abstract}

Kata kunci: sel Clara, bronkiolus, PPOK

\begin{abstract}
Chronic obstructive pulmonary disease (COPD) and asthma are global health problems which increase comorbidities and therapy costs. This has led researchers to find out strategies that can be used to prevent, detect and intervene the chronic lung diseases in order to develop specific and effective therapies for the diseases. This article aimed at describing the characteristic of Clara cells (a type of cell in lung bronchioles wall) and its role in chronic lung infection. Previous research studies provided some evidences of an imparment of Clara cell functions due to epithelial remodeling as seen in chronic lung infection. It is obvious that Clara cells are able to regulate inflammatory process via regulation of macrophage behavior (anti-inflammatory effect) and are able to restore damaged respiratory epithelial cells into the normal ones (stem cells progenitor). Based on these functions, it is expected that Clara cells can be used as a basis for developing the latest therapies in the treatment of chronic lung infection.
\end{abstract}

Keywords: Clara cell, bronchiolus, COPD

Afiliasi Penulis : 1. Bagian Histologi Program Studi Pendidikan Dokter, FKUNLAM Kalsel 2. Departeman Histologi, FKUI Jakarta, Korespondensi: Bagian Histologi Program Studi Pendidikan Dokter, FK UNLAM Kalsel, email: dr.idayuliana@gmail.com 


\section{PENDAHULUAN}

Penyakit paru kronik seperti chronic obstructive pulmonary disease (COPD) and asma merupakan masalah kesehatan secara global. COPD diperkirakan menjadi penyebab ketiga kesakitan tahun 2020 dan asma sekarang diderita 300 juta penduduk dunia. Menurut perkiraan WHO (World Health Organization) sekitar 80 juta pasien menderita COPD pada tahun 2005, terhitung $5 \%$ kasus mengalami kematian. COPD merupakan penyebab ke 4 teratas dari kematian di dunia. Keberadaan COPD pada pasien berhubungan dengan tingkat kualitas hidup yang menyebabkan komorbiditas meningkat, biaya pemeliharaan penyakit secara langsung juga terpengaruh, di Belanda pada tahun 2000 biaya pemeliharaan kesehatan berkisar 0,28 juta euro bahkan 20,9 juta dolar di USA di tahun 2004.

Hal ini telah membuat para peneliti mencoba mencari berbagai hal yang dapat digunakan untuk dapat mencegah, dan mendeteksi serta mengintervensi penyakit paru kronik agar didapatkan terapi yang efektif dan spesifik untuk penyakit tersebut. Berikut akan disampaikan sel pada paru manusia yang mempunyai peranan dalam penyakit paru kronik yaitu sel Clara yang berpotensi dikembangkan sebagai dasar pengembangan terapi dalam pengobatan COPD.

\section{METODE}

Penulisan artikel ini berdasarkan studi kepustakaan yang terkait dengan peranan sel Clara pada infeksi paru kronis.

\section{HASIL DAN PEMBAHASAN}

\section{Sejarah}

Sel Clara merupakan sel epitel sekretori tidak bersilia yang berada disepanjang bronchiolus, sel ini berbeda secara morfologi dan produk yang dihasilkannya dibandingkan sel yang mensekresikan serous dan mukus. Sel ini pertama kali dikenali sebagai tipe sel yang berbeda di bronchiolus secara morfologi dan histokimia oleh Kolliker pada tahun $1881 .{ }^{1}$

Pada tahun 1937, Max Clara berhasil menggambarkan isi sel yang sama ditemukan oleh Kolliker pada paru manusia. Karena penemuannya ini maka sel yang ditemukan tersebut diberi nama "Clara Cell". Dia menemukan adanya granula pada sel yang menandakan tipe sel eksokrin. Penelitian Kuhn menunjukkan granula pada sel Clara berisi protein yang membedakannya dari sel sekretori mukus. ${ }^{2}$

Tahun 1967, Niden menduga bahwa sel Clara mensekresikan surfaktan paru dan adanya lamellar bodies yang juga terdapat pada sel alveolar tipe II yang berperan sebagai makrofag surfaktan. Postulat ini ternyata tidak terbukti benar; Kuhn melanjutkan penelitian sel pada paru, hasil penelitiannya menunjukkan bahwa lipid surfaktan di sintesa sel alveolar tipe II sedangkan sel Clara tidak mensekresikan surfaktan. Namun dugaan Niden tidak sepenuhnya salah karena protein yang berkaitan dengan surfaktan seperti surfaktan protein $A, B$, dan $D$ di sintesa oleh sel Clara dan sel Clara $10 \mathrm{kDa}$ protein (CC 10) terikat lipid surfaktan. ${ }^{1}$ 
Studi awal sel Clara lebih dipusatkan pada morfologi dan mekanisme proses sekresinya berdasarkan observasi secara histologi. Yoneda menduga jika sel Clara melepaskan granula sekretorinya melalui mekanisme merokrin. Tapi peneliti lain menyatakan mekanisme sekresi secara apokrin dan merokrin. Sampai sekarang mekanisme sekresi sel Clara masih kontroversil. Seiring penelitian tersebut, dipelajari juga regulasi sekresi melalui pengukuran morfometrik densitas volume granula di sel Clara. Massaro melakukan penelitian yang menemukan jika proses sekresi sel Clara di pengaruhi stimulasi adrenergik. ${ }^{3}$

\section{Histologi Sel Clara}

Sel Clara merupakan sel epitel kuboid bronchiolus respirasi dengan nukleus pada basal sitoplasma, sitoplasma bentuk dome-shaped tanpa silia, banyak retikulum endoplasmik, granula berikatan dengan membran, kompleks Golgi yang berkembang baik dan tingginya aktivitas enzim oksidatif menandakan fungsi sekresi.

Penelitian Blanco et al (1994) menemukan gambaran sel Clara dari fetus tikus pada mikroskop cahaya akan tampak 2 tipe granula sekretori yaitu grup dengan jumlah terkecil- ditandai densitas elektron tinggi berada di apex sitoplasma dengan sejumlah sekret di dalamnya dan grup lainnya dengan jumlah sel terbesar, berlokasi di pertengahan sitoplasma mempunyai densitas lebih rendah. ${ }^{4}$

Studi biokomia juga menunjukkan keberadaan enzim yang mengkatabolisme fosfolipid. Berdasarkan hipotesa tersebut sel Clara ikut serta berperan dalam katabolisme fosfolipid surfaktan paru, dimana terdapat aktifitas hidrolase lipid secara sitokimia. ${ }^{4}$

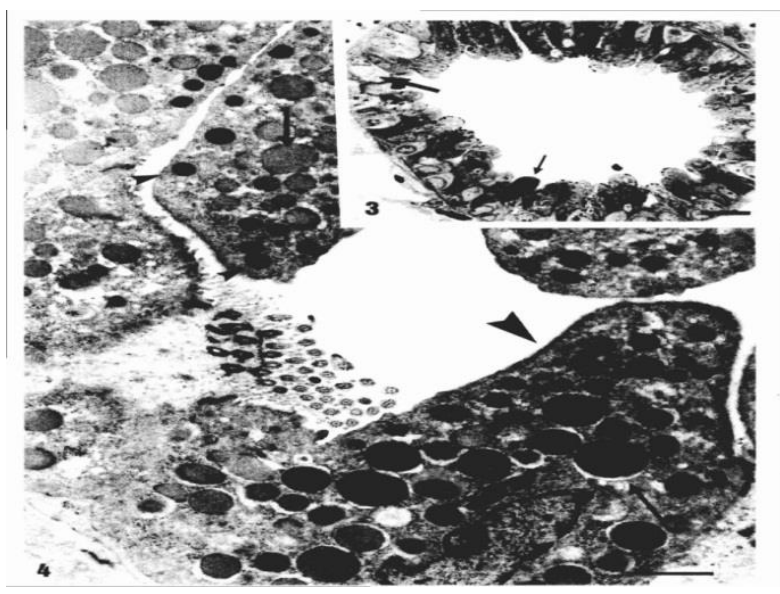

Gambar 1. Sel Clara (panah kecil), sel epitel bersilia (panah besar) dan sel Clara (kepala panah) menunjukkan 2 tipe granula osmofilik dan nonosmofilik (kepala panah kecil). ${ }^{4}$

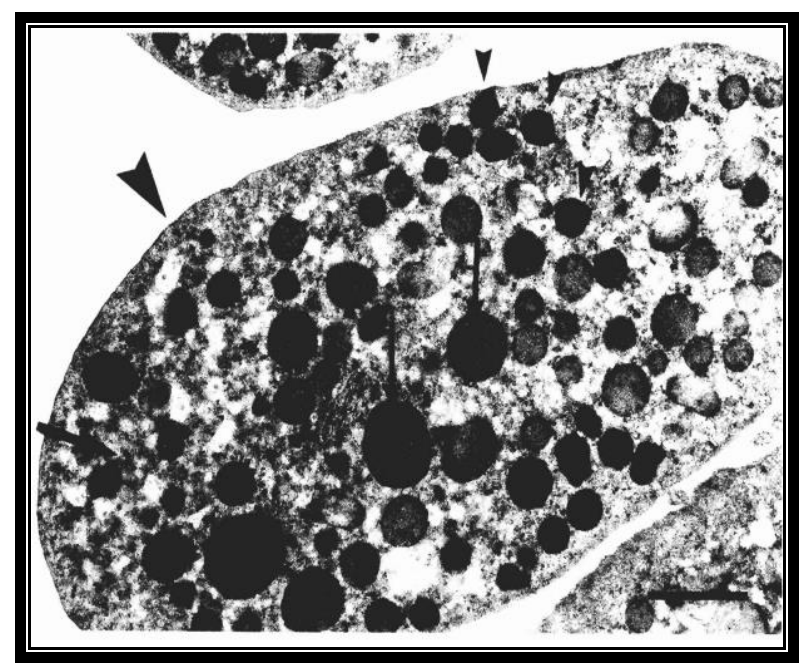

Gambar 2. Sel Clara (kepala panah besar) menunjukkan 2 tipe granula (osmofilik; kepala panah kecil, dan non-osmofilik; panah kecil) dan retikulum endoplasmik halus (panah kecil) dikelilingi mikrovesikel. Grup I. Bar $=1$ pm. ${ }^{4}$

\section{Produk Sekresi Sel Clara}

Produk yang di sekresi sel Clara (CCSP / Clara cell Secretory Protein) atau CC10, CC16 adalah uteroglobin 
atau blastokinin. Uteroglobin pada paru di identifikasi pertama kali pada kelinci dan spesies sejenis sebagai protein dengan berat molekul rendah yang sama ditemukan pada endometrium saat gravid. Expresi uteroglobin juga ditemukan pada sel epitel oviduct, traktus genitalis pria dan traktus digestivus ${ }^{1}$

Pada kebanyakan studi yang dilakukan berkaitan dengan peranan uteroglobin lebih dipusatkan pada fungsi reproduksi, meski ekspresi pada paru sudah diidentifikasi pada kelinci. Pada studi eksplorasi cairan paru oleh Singh dan Katyal mengidentifikasi protein 10 $\mathrm{kD}$ yang secara primer diekspresikan sel Clara bronchiolus pada tikus dan manusia mempunyai struktur protein mirip dengan uteroglobin pada kelinci. Protein ini dinamai pada literatur sebagai uteroglobin, Clara cell secretory protein (CCSP), Clara cell 16 kD protein, Clara cell $10 \mathrm{kD}$ protein (CC10), human protein 1 , urine protein 1 , dan polychlorinated biphenyl-binding protein. Protein CC10 pada manusia tidak berikatan dengan progesteron namun berperan sebagai inhibitor phospholipase A2. Berdasarkan pemeriksaan ditemukan materi lain dari CC10 berupa protease inhibition, dan ikatan terhadap hormon steroid lain yang belum diketahui kontribusinya. ${ }^{1}$

Lokasi gen CC10 pada manusia terdapat pada kromosom 11, p12-q13, yang merupakan regio gen yang terlibat dalam regulasi inflamasi. Jadi dapat diasumsikan bahwa penemuan inhibisi phospholipase A2, ikatan phospholipase A2 substrate (phosphatidylcholine) oleh CC10, serta lokasi gen CC10 didaerah yang terlibat dalam regulasi inflamasi makin menguatkan fungsi CC10 sebagai regulator inflamasi di paru. ${ }^{1}$
Protein 16 kD telah ditemukan pada epitel paru tikus maupun manusia. Protein ini mempunyai kemampuan sebagai natural immunosuppresor. Pada adult respiratory distress sindrome (ARDS) sebagai proses perlukaan paru akut dengan faktor predisposisi seperti sepsis, trauma dan sirkulasi extracorporal, ditemukan akumulasi sejumlah pelepasan mediator inflamasi oleh makrofag dan neutrofil selama perlukaan paru akut berlangsung yang ditandai keberadaannya pada cairan lavage bronchoalveolar (BALF). Studi yang dilakukan P.G. Jorens et al menunjukkan bahwa sel epitel respirasi dapat memproduksi mediator sehingga mempunyai kemampuan memodulasi respon inflamasi selama terjadi kerusakan pada paru. Hal ini diketahui dari nilai konsentasi CC 16 pada BALF pasien ARDS secara signifikan terdeteksi dalam jumlah yang tinggi pada BALF pasien yang mengalami perlukaan paru akut. Sehingga dapat di duga bahwa sel epitel paru mensekresikan protein natural antiinflammatory selama perlukaan paru akut yang menandakan adanya peran proteksi dan immunosupresi sel Clara. Hanya beberapa tipe sel saja yang memproduksi dan mensekresikan protein CC 16 salah satunya adalah dari granula sekretori sel Clara. Pada manusia dan tikus, CC 16 homolog dengan uteroglobin kelinci karena berasal dari gen ancestral yang sama. ${ }^{3}$

Uteroglobin merupakan protein yang diregulasi oleh hormon, homodimer, dan protein sekretorik. Memiliki materi biologis termasuk inhibisi poten dari phospholipase A2 (PLA2). Dengan in situ hybridization pada paru kelinci ditemukan uteroglobin pada sel epitel bersilia dan sel epitel di bronchiolus. 
Uteroglobin berfungsi sebagai agen antiinflamasi karena kemampuan menginhibisi aktivasi PLA2 (enzim yang terlibat dalam produksi prostaglandin dan eicosanoid lain), menginhibisi agregasi platelet yang menginduksi trombin, dan pada manusia dan kelinci sebagai fagosit kemotaksis. Selain berperan sebagai anti-inflamasi, terdapat hipotesis jika uteroglobin juga berperan penting pada peningkatan masa half-time surfactans dengan mempertahankan hidrolisisnya oleh PLA2 dan oleh penurunan level eicosanoids melalui inhibisi PLA2. ${ }^{3}$

\section{Fungsi Sel Clara pada Paru}

Fungsi utama dari sel Clara yang diketahui adalah memproteksi epitel bronchiolus sekaligus sebagai sel progenitor saat terjadi kerusakan epitel bronchiolus. Sel Clara di bronchilous mempunyai kemampuan untuk berdiferensiasi menjadi sel Clara dan sel epitel respirasi yang bersilia sehingga dapat dikatakan sel Clara sebagai stem cell. ${ }^{5}$

Brody et al melakukan investigasi pada sel Clara yang diisolasi kemudian di implantasikan pada trakea yang dibuat rusak, selanjutnya di nilai restorasi epitel tersebut. Ternyata terjadi perkembangan ke arah normal dari sel yang rusak sehingga menjadi bukti bahwa sel Clara memiliki peran sebagai sel progenitor pada epitel respiratorik yang rusak. Penelitian serupa juga dilakukan Plopper, Stripp, dan Stahlman dengan cara menginduksikan kerusakan epitel di saluran napas, sel Clara menyebabkan penyembuhan epitel termasuk sel epitel bersilia. $^{6}$

Hal ini juga di duga akibat kemampuan migrasi sel Clara ke jaringan atau sel yang rusak. Jeffrey J Atkinson et al menemukan mekanisme sel Clara melakukan migrasi ke jaringan paru yang mengalami perlukaan. ${ }^{6}$

Fungsi sel Clara yang lain adalah mensekresikan komponen cairan yang mirip dengan surfaktan paru. Pada tahun 1967, Niden menduga sel Clara mensekresikan surfaktan paru dan lamellar bodies seperti pada sel alveolar tipe II yang berperan sebagai fagositosis surfaktan. Postulat Niden terbukti tidak benar melalui penelitian-penelitian selanjutnya seperti yang dibuktikan dari studi oleh Kuhn dan studi Etherton (1973). Tapi ada kemungkinan sel Clara tidak sepenuhnya tidak terlibat dalam kemampuan biologis surfaktan, hal ini dikarenakan pada sel Clara memiliki 2 protein yang memiliki kaitan dengan surfaktan yaitu protein surfaktan $A$ dan $D$ yang disintesa oleh sel Clara dan CC 10 mampu berikatan dengan lipid surfaktan. ${ }^{1,7}$

Fungsi sel Clara adalah mendetoksifikasi substansi berbahaya yang terhirup masuk dalam paru dengan bantuan enzim sitokrom P 450 yang ada pada smooth endoplasmic reticulum. Christensen et al. (1987) pada hamster menemukan kemampuan sel Clara menyimpan isoenzim $\mathrm{P} 450$ dalam fraksi mikrosomal. ${ }^{8}$

\section{Peranan Sel Clara pada Infeksi Paru Kronis}

Pada penyakit kronis terjadi proses remodelling paru termasuk di dalamnya perubahan materi di dalam epitel respirasi, fibrosis subepitelial, peningkatan penebalan membran basal dan hipertropi otot polos. Karakteristik perubahan patologis dalam epitel saluran pernapasan terintegrasi pada inisiasi dan progresi PPOK. Terjadi hiperplasia epitel, hiperplasia sel sekretori mukus, 
metaplasia squamosa, dan akumulasi mukus. $^{9}$

Kondisi patologis ini diperparah oleh proses inflamasi yang berat yang secara bermakna menurunkan fungsi paru, kesakitan, pembatasan dan kematian akibat infeksi paru. Level CCSP secara dramatis menurun pada serum atau cairan saluran napas pada pasien PPOK, asma, displasia bronchopulmonari, silikosis, dan rejeksi post transplantasi. $^{3}$

Penelitian telah membuktikan hipotesis bahwa sel Clara mempunyai kemampuan meregulasi respon paru terhadap perangsangan inflamasi. Telah diketahui dari penelitian yang dilakukan Harrod et al dan Hayashida et al terjadi penurunan ekspresi sel Clara pada tikus yang dikembangkan dari 2 jalur fenotip berbeda tapi masing-masing menunjukkan kerentanan terhadap perubahan terhadap agen lingkungan dan induksi terkait perlukaan dari jaringan inflamasi. Untuk tikus yang didesain mengalami defisiensi CCSP diinduksikan secara intratrakea Pseudomonas aueroginosa (memproduksi sejumlah faktor virulensi yang dapat menghancurkan mekanisme defensif host dan memfasilitasi infeksi paru) ternyata terjadi peningkatan respon inflamasi terhadap Pseudomonas aeruginosa di paru. Yang dinilai pada penelitian tersebut adalah peningkatan total eksudat sel inflamasi di bilasan cairan bronkoalveolar dan sekresi proinflammatory sitokin yang mengindikasikan peranan regulasi CCSP pada imunitas innate. Namun penelitian ini belum bisa menjelaskan mekanisme molekular bagaimana regulasi CCSP terhadap respon inflamasi. ${ }^{3}$

Joshua C. Snyder (2008) meneliti lebih lanjut mekanisme molekular regu- lasi CCSP dari hasil penelitian tersebut didapatkan bahwa terjadi perubahan penambahan respon inflamasi pada tikus yang mengalami deplesi CCSP dan tikus yang di induksi P.aureginosa yang ditunjukkan dari hasil pemeriksaan terjadi peningkatan sel leukosit PMN, terjadi peningkatan ekspresi signal TNF alfa pada pemeriksaan ekspresi gen yang menunjukkan bahwa makrofag pada tikus mengalami peningkatan ekspresi toll-like receptor pada permukaan selnya. Hasil ini membuktikan bahwa sel Clara dapat melemahkan inflamasi melalui regulasi perilaku makrofag dan menunjukkan bahwa remodelling pada epitel menyebabkan penurunan fungsi sekretori sel Clara sehingga meningkatkan intensitas inflamasi paru pada infeksi paru kronik. ${ }^{3}$

Pada saluran napas dewasa normal fungsi sel Clara berespon terhadap agen inflamasi yang terinhalasi pada prosesnya melibatkan pengaruh parakrin sekresi sel Clara pada makrofag paru. Sehingga jika terjadi disfungsi sekresi sel Clara akibat remodelling epitel menyebabkan hilangnya materi immunosupresi intrinsik yang di miliki sel epitel dan berlanjut menjadi penyebab eksaserbasi respon inflamasi. Jadi ciri khas pada pasien penyakit paru kronik terjadi penurunan fungsi sel Clara dan peningkatan respon imun melalui aktifitas makrofag dan sel leukosit PMN. Penelitian ini juga menemukan bahwa defisiensi CCSP menyebabkan perubahan post-translational modification dari annexin A1 yang berada dalam sel bersilia dan makrofag yang berfungsi sebagai sel epitel dan sel inflamasi yang mungkin dipengaruhi oleh sekresi sel Clara melalui mekanisme signal parakrin dan kandidat reseptor yang menunjukkan ekspresi berinteraksi 
dengan reseptor makrofag adalah SCGB3A2. ${ }^{3}$

\section{SIMPULAN}

Sel Clara adalah salah satu sel epitel pada dinding bronchiolus yang mempunyai fungsi luas. Pada infeksi paru kronis sel Clara mempunyai fungsi meregulasi respon inflamasi melalui pengubahan perilaku makrofag. Dengan diketahuinya karakteristik dan fungsi sel Clara pada penyakit paru kronis maka membuka jalan bagi peneliti untuk lebih mengeksplorasi sisi lain sel Clara, sedangkan untuk klinisi pengetahuan tentang sel Clara ini dapat dijadikan dasar dalam melakukan terapi selanjutnya berkaitan dengan penyakit infeksi paru kronis.

\section{DAFTAR RUJUKAN}

1. Singh G, Sikandar L. Katyal. Perspective Clara Cells and clara cell $10 \mathrm{kD}$ protein (CC 10) . Am J Respir Cell Mol Biol.. 1997; 17(2): 141-3.

2. Wang SZ, Rosenberger CL, Bao YX, Stark JM, Harrod KS. Clara Cell Secretory Protein Modulates Lung Inflammatory and Immune Responses to Respiratory Syncytial Virus Infection. J Immunol. 2003; 71(2):1051-60.
3. Snyder JC, Reynolds SD, Hollingsworth JW, Li Z, Kaminski N, Stripp BR. 2010. Clara Cells Attenuate the inflammatory Response through Regulation of Macrophage Behavior. Am J Respir Cell Mol Biol.. 2010; 42(2):161-71

4. Blanco A, Méndez A, Carrasco L, Bautista MJ, Sierra MA. Morphology and changes in Clara cells in the foetal bronchioles of Swiss mice. Histol Histopath. 1994; 9(2):251-8

5. Hermans $C$, Knoops B, Wiedig M, Arsalane $\mathrm{K}$, Toubeau G, Falmagne $\mathrm{P}$, et al. Clara cell protein as a marker of Clara cell damage and bronchoalveolar blood barrier permeability. Eur Respir J. 1999; 13(5):1014-21

6. Atkinson JJ, Adair-Kirk TL, Kelley DG, Demello D, Senior RM. Clara cell adhesion and migration to extracellular matrix. Respir Res. 2008; 9:1-11

7. Jorens PG, Sibille $Y$, Goulding NJ, van Overveld FJ, Herman AG, Bossaert L, et al. Potential role of Clara cell protein, an endogenous phospholipase A2 inhibitor, in acute lung injury. Eur Respir J. 1995; 8(10):1647-53.

8. Yoneda K. Ultrastructural Localization of Phospholipases in the Clara Cell of the Rat Bronchiole. Am J Pathol. 1978; 93(3): 745752.

9. Randell SH. Airway Epithelial Stem Cells and the Pathophysiology of Chronic Obstructive Pulmonary Disease. Proc Am Thorac Soc. 2006; 3(8):718-25 